\title{
Substrates to produce Jambolan (Syzygium cumini) seedlings
}

\author{
Geany Giovana Silva da Costa ${ }^{1}$, Edilson Costa ${ }^{1}$, Eliana Duarte Cardoso ${ }^{1}$, Flávio Ferreira da Silva Binotti ${ }^{1}$, \\ Alan Mario Zuffo ${ }^{1}$, Marçal Henrique Amici Jorge ${ }^{2}$ and Tiago Zoz $^{1}$
}

\author{
'Department of Crop Production, State University of Mato Grosso do Sul, 79540-000, Cassilândia, Mato Grosso do \\ Sul, Brazil \\ ${ }^{2}$ Brazilian Agricultural Research Corporation (Embrapa Hortaliças), 70275-970, Distrito Federal, Brasília, Brazil
}

*Corresponding author: alan_zuffo@hotmail.com

\begin{abstract}
Jambolan (Syzygium cumini L., also known as jambul, java plum, Portuguese plum, among others) is used as an ornamental, medicinal and edible plant and, given its large and diverse uses, high-quality seedlings are desired for fruit farming. This study sought to evaluate the growth and formation of Syzygium cumini seedlings in several substrates. The experiment was conducted in a completely randomized design, with 13 treatments comparing different substrates (S) made with different proportions of bovine manure, subsurface soil, Bioplant, superfine vermiculite and fine sand. Growth variables of the seedlings, such as height, stem base diameter, mass and biometric ratios were evaluated. Substrates containing 10 to 30\% bovine manure and 20 to $40 \%$ vermiculite, as in $\mathrm{S} 7(30 \% \mathrm{BM}+30 \% \mathrm{SS}+10 \% \mathrm{BP}+20 \% \mathrm{FV}+10 \% \mathrm{FS})$ and $\mathrm{S} 9(\mathrm{~S} 9=10 \% \mathrm{BM}+30 \% \mathrm{SS}+10 \% \mathrm{BP}+40 \% \mathrm{FV}+10 \% \mathrm{FS})$, yielded the best seedlings with adequate values for diameter, mass and Dickson quality index. Substrates with the largest amounts of bovine manure $(50 \%)$ showed the worst mass distributions. Substrates with high amounts of Bioplant or fine sand are not recommended for jambolan seedling formation.
\end{abstract}

Keywords: Dickson quality index, bovine manure, sand, vermiculite, soil.

Abbreviations: BM_bovine manure; SS_subsurface soil; BP_Bioplant ; FV_superfine vermiculite; FS_fine sand; H_Plant height; CD_stem base diameter; HDR_height/stem base diameter ratio; SDM_Shoot dry mass; RDM_root dry mass; TDM_total dry mass; SMR_shoot/root dry mass ratio; RMR_root/total dry mass ratio; DQI_Dickson quality index; RGR_relative growth rate; DAS_days after sowing.

\section{Introduction}

Syzygium cumini L., also known as jambul, java plum, Portuguese plum, among others, belongs to the Myrtaceae family and has nutritional properties that prevent diabetes and high antioxidant activity, among other medicinal uses. The Syzygium cumini fruit is more often consumed in nature, but the tree can be used ornamentally, often in parks, squares, and gardens (Mazzanti et al., 2003). This fruit plant native to India and of great rusticity adapted itself to the Brazilian edaphoclimatic conditions, mainly in Northeast Brazil, with trees reaching up to $10 \mathrm{~m}$ in height and branched canopy with several fruits (Souza and Lorenzi 2005).

The fruits are berry-like, small and ovoid, and the fruiting period takes place from January to May in Brazil. The fruit goes through three stages of coloration during its cycle, changing from green to pink to blood red to black as it matures, with fleshy pulp and little astringent taste (Cavalcanti, 2010).

Syzygium cumini propagation usually takes place by seeds, which can cause various problems in descendant plants and failures in seedling formation. Another factor that hampers seedling formation is the difficulty in separating the embryos at thinning because this is a polyembryonic species (Cavalcanti, 2010).
Substrates strongly influence the quality of the seedlings, as they provide them with nutrients and water for the development and growth and act as support and fixation for the root. Substrates should be free of soil pathogens and invasive plant seeds and should be available at the seedling production site (Oliveira and Jardim, 2013). The mixture of sand and bovine manure gave greater root volume to the Syzygium cumini seedlings, while the combination of manure, sand, and soil favored the seedlings' growth as a whole (Cavalcanti, 2011). For other fruits has been reported the use of manure associated with vermiculite as favoring the formation of high-quality seedlings. For example, Baru (Dipteryx alata Vog) (Costa et al., 2015), passion fruit (Passiflora edulis) (Lima et al., 2016), jatobá (Hymenaea courbaril) (Sanches et al., 2017) and mangaba (Hancornia speciosa) (Arrua et al., 2016).

For use a material as a substrate, some things must be considered like the species that will be cultivated and the time required for its growth which, added to the type of container, can limit the growth of the root system. Additionally, many studies in the literature emphasize that substrates must provide adequate physical conditions for the development of seedlings, such as aeration, water 
retention capacity, structure, good porosity and other characteristics that may or may not favor seed germination. Given the need to increase knowledge about the cultivation of fruit species, this study sought to evaluate the growth and formation of seedlings of Syzygium cumini L. cultivated in different substrates, in an attempt to obtain high-quality seedlings for commercial farming.

\section{Results and Discussion}

\section{Plant growth and development}

At 30 DAS, the plants cultivated in substrates S1, S2, S8 and S12 differed from the plants grown in S5, showing higher average heights, but they did not differ from the remainder of treatments (Table 4). At 60 DAS, the seedlings in substrates S1 and S7 were larger than those grown in substrates S3, S4, S5, S11, and S13. At 90 DAS, the seedlings of S1, S2, and S6 were larger than those cultivated in substrates S3, S4, S5, S11, S12, and S13.

Concerning the height parameter, it was observed that at 90 DAS the substrates containing 40 to $50 \%$ bovine manure showed higher growth in height, but still with similar results to the substrates with fewer amounts of manure, 10 to $30 \%$, and larger amounts of vermiculite, 20 to $40 \%$. It evinced that the physical and chemical properties of such substrates were adequate to the Syzygium cumini seedlings (Table 4).

Results in the literature on Syzygium cumini seedlings show that larger seedlings were obtained in substrates with $33.33 \%$ bovine manure (Cavalcanti, 2010). At 60 DAS, the seedlings reached a height of $20.84 \mathrm{~cm}$ in $\mathrm{S1}$, and $18.52 \mathrm{~cm}$ in $\mathrm{S} 2$, and $18.28 \mathrm{~cm}$ in $\mathrm{S} 6$, superior results to those achieved by Cavalcanti (2010), who obtained seedlings of $16.1 \mathrm{~cm}$ at 52 DAS. The use of more than $30 \%$ bovine manure in substrates was not recommended by Costa et al. (2015) for Baru (Dipteryx alata Vog), Dias et al. (2009a), by Silva et al. (2009) for mangaba (Hancornia speciosa Gomez), by Dias et al. (2009) for coffee (Coffea arabica L.) and by Cavalcanti (2010) for Syzygium jambolanum Lam.. The results obtained for seedling height in the present study showed similar values for the use of 10 to $30 \%$ bovine manure with the addition of 20 to $40 \%$ vermiculite, in comparison to substrates S1, S2 and S6 (90 DAS) using 40 to $50 \%$ manure. At 90 DAS, it was verified in substrates S1 and S2 the seedlings presented a larger stem base diameter $(4.39 \mathrm{~mm}$ and $4.40 \mathrm{~mm}$, respectively) when compared to those cultivated in substrates S3, S4, S5, S11, and S13, which are higher values than those achieved by Cavalcanti (2010), who reported $3.2 \mathrm{~mm}$ diameters for Syzygium cumini seedlings at 52 DAS.

Height/stem base diameter ratio allow evaluating the level of etiolation and the leaning potential of the seedlings when submitted to the field conditions. In the experiment, substrate S13 presented a low height/stem base diameter ratio, but not different from that of substrates S5 and S12 (Table 4). Carneiro (1995) examined in Eucalyptus (Eucalyptus spp) seedlings that a height/stem base diameter ratio ranging from 5.4 to 8.1 is within the range classified as adequate, so substrate $S 6$ in the present experiment did not fit this adequate range. It is important to consider, however, that for some species this is not a suitable parameter (Table 4).
Substrates containing 20 and 40\% Bioplant (S11 and S13), as well as substrates containing 20,30 and $40 \%$ fine sand (S3, S4, and S5) did not yield adequate diameters or heights for Syzygium cumini seedlings. It is because Bioplant ${ }^{\circledR}$ did not provide the seedling with satisfactory nutritional (nutrient availability) and physical conditions for its growth when compared to bovine manure. The same result was observed for the use of vermiculite in detriment of sand, showing adequate physical conditions for the substrate, such as high water retention, high porosity, low density and high CEC. These results corroborate with those obtained by Borges et al. (2016) who stated that Bioplant ${ }^{\circledR}$, even supplemented with other compounds such as vermiculite and coconut powder at proportions of $20 \%$ to $40 \%$, did not increase the height of Eugenia calycina plants.

Shoot dry mass (SDM), root dry mass (RDM), and total dry mass (TDM) of the seedlings grown in substrate 59 were higher than those cultivated in substrates S3, S4, S5, S11, and S13, however not different from the remaining substrates (Table 5).

Substrate S9 was composed of $40 \%$ superfine vermiculite, and it is known that this component improves the physical and chemical conditions of the substrate because it releases magnesium ions to the solution thereof and absorbs phosphorus and nitrogen in the ammoniacal form. Vermiculite together with organic manure matter provided adequate conditions for the accumulation of dry matter, as can be seen in substrates S1, S7, S8, S10, and S12. Possibly, this mixture gave the substrate better physical and chemical conditions, regulating the water and oxygen supply for the roots. It also provided chemical elements for nutrition, promoting the satisfactory development of the Syzygium cumini seedlings, with larger dry masses. The same was observed for other fruits, such as Baru (Dipteryx alata Vog) (Costa et al., 2015), passion fruit (Passiflora edulis) (Lima et al., 2016), jatobá (Hymenaea courbaril) (Sanches et al., 2017) and mangaba (Hancornia speciosa) (Arrua et al., 2016).

It was observed that the substrates containing 20 and $40 \%$ Bioplant (S11 and S13), as well as those containing 20, 30 and $40 \%$ fine sand (S3, S4, and $\mathrm{S} 5$ ), presented the lowest dry masses in Syzygium cumini plants (Table 5). Fine sand particles are smaller than superfine and medium vermiculite particles, so the substrates with high amounts of such materials presented lower microporosity, as mentioned by Smiderle et al. (2001) for a substrate with $33.33 \%$ of sand, showing lower total porous space. A similar situation may have occurred to the substrates with 20,30 and $40 \%$ fine sand (S3, S4, and S5, respectively), which did not provide adequate physical conditions for mass accumulation in the Syzygium cumini seedlings.

The negative effect of Bioplant mixed with fine sand in the substrates for Syzygium cumini seedlings may be related to the physical and chemical characteristics of these components, which do not allow adequate growth of shoot, root and total masses. Alves et al. (2012) reported that, for seedlings of Crateva tapia L. submitted to a temperature of 20 으 $30 \circ \mathrm{C}$, the use of Bioplant ${ }^{\circ}$ did not promote adequate root development. Dutra et al. (2012) reported that, in the production of Copaíba (Copaifera langsdorffii Desf.) seedlings, Bioplant presented lower results for shoot dry mass, total dry mass, and shoot/total dry mass ratio, compared to substrates composed of vermiculite and carbonized rice hulls. The same authors reported that the 
Table 1. Substrates made with mixtures in different proportions of bovine manure (BM), subsurface soil (SS), Bioplant ${ }^{\bullet}$ (BP), superfine vermiculite (FV) and fine sand (FS).

\begin{tabular}{|c|c|c|c|c|c|c|c|}
\hline Substrates & Bovine Manure (BM\%) & Subsurface Soil (SS\%) & Bioplant (BP\%) & $\begin{array}{l}\text { Superfine } \\
\text { (FV\%) }\end{array}$ & Vermiculite & $\begin{array}{l}\text { Fine } \\
\text { (FS\%) }\end{array}$ & Sand \\
\hline S1 & 50 & 30 & 10 & 10 & & 0 & \\
\hline S2 & 40 & 30 & 10 & 10 & & 10 & \\
\hline S3 & 30 & 30 & 10 & 10 & & 20 & \\
\hline S4 & 20 & 30 & 10 & 10 & & 30 & \\
\hline S5 & 10 & 30 & 10 & 10 & & 40 & \\
\hline S6 & 50 & 30 & 10 & 0 & & 10 & \\
\hline S7 & 30 & 30 & 10 & 20 & & 10 & \\
\hline S8 & 20 & 30 & 10 & 30 & & 10 & \\
\hline s9 & 10 & 30 & 10 & 40 & & 10 & \\
\hline S10 & 50 & 30 & 0 & 10 & & 10 & \\
\hline S11 & 30 & 30 & 20 & 10 & & 10 & \\
\hline S12 & 20 & 30 & 30 & 10 & & 10 & \\
\hline $\mathrm{S} 13$ & 10 & 30 & 40 & 0 & & 10 & \\
\hline
\end{tabular}
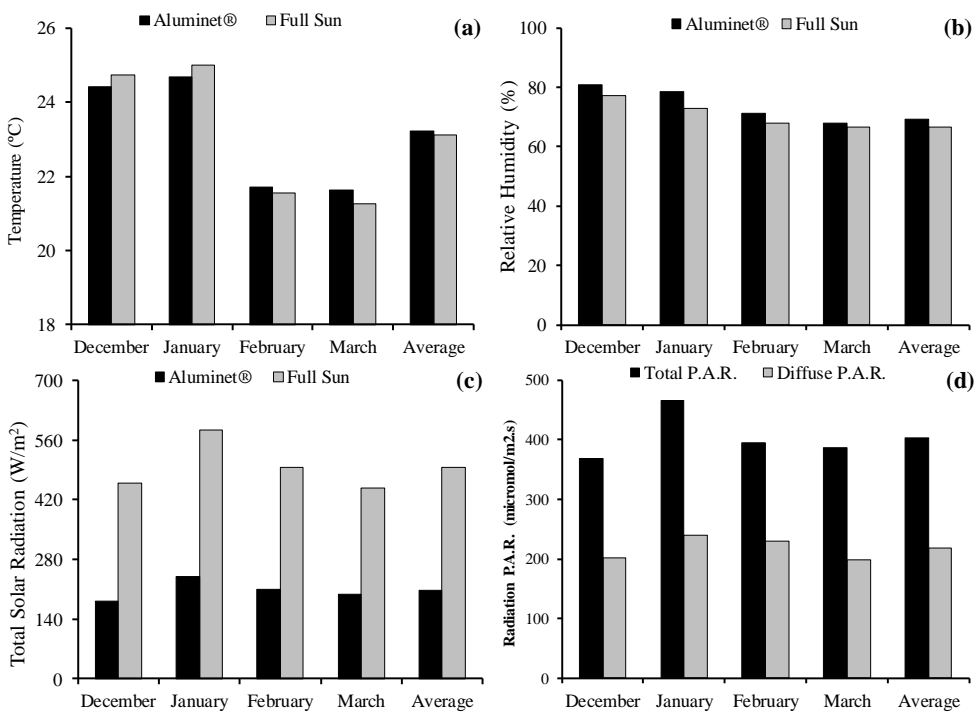

Fig 1. Temperature (a), relative humidity (b), total solar radiation (c) and total and diffuse photosynthetically active radiation (d) recorded for the protected and the full sun environments during the experimental period.

Table 2. Bovine manure analysis, Cassilândia- MS, Brazil, 2014-2015.

\begin{tabular}{|c|c|c|c|c|c|c|c|}
\hline$N$ & $\mathrm{P}_{2} \mathrm{O}_{5}$ & $\mathrm{~K}_{2} \mathrm{O}$ & $\mathrm{Ca}$ & $\mathrm{Mg}$ & $S$ & $M-65 \div C$ & $C$ \\
\hline 0.9 & 0.3 & 0.1 & 0.3 & 0.1 & 0.2 & 2.0 & 11.0 \\
\hline $\mathrm{Na}$ & $\mathrm{Cu}$ & $\begin{array}{c}\mathrm{Fe} \\
\mathrm{kg}^{-1}\end{array}$ & $\mathrm{Mn}$ & $\mathrm{Zn}$ & $\mathrm{C} / \mathrm{N}$ & $\mathrm{pH}$ & OM \\
\hline 624 & 18 & 12103 & 204 & 53 & $12 / 1$ & $5.3^{2}$ & 20.0 \\
\hline
\end{tabular}

$\mathrm{M}=$ moisture; $\mathrm{OM}=$ organic matter; $\mathrm{C} / \mathrm{N}=$ carbon and nitrogen ratio.

Table 3. Subsurface soil analysis, Cassilândia-MS, Brazil, 2014-2015.

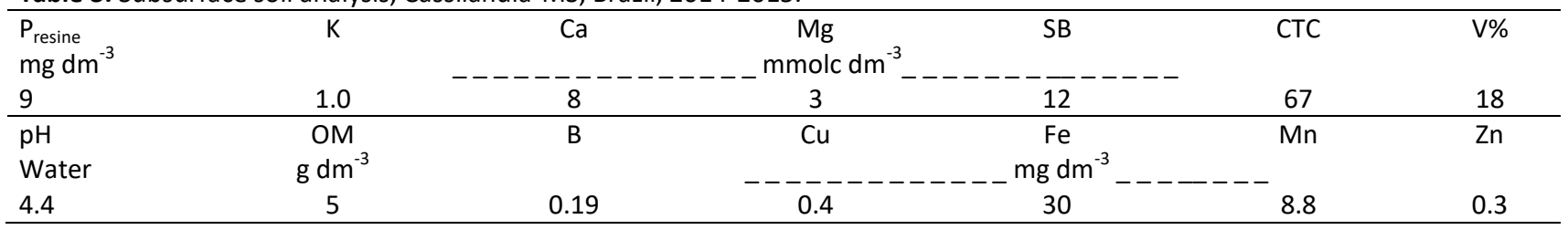

$\mathrm{OM}=$ organic matter 
Table 4. Plant height $(\mathrm{H}, \mathrm{cm})$ at $30(\mathrm{H} 1), 60(\mathrm{H} 2)$ and $90(\mathrm{H} 3)$ DAS, stem base diameter $(\mathrm{CD}, \mathrm{mm})$ at 90 DAS and height/stem base diameter ratio (HDR) of Syzygium cumini seedlings. Cassilândia, MS, Brazil, 2014-2015.

\begin{tabular}{llllll}
\hline Substrates & $\begin{array}{l}\mathrm{H} 1 \\
\text { (30 DAS) }\end{array}$ & $\begin{array}{l}\mathrm{H} 2 \\
\text { (60 DAS) }\end{array}$ & $\begin{array}{l}\text { H3 } \\
\text { (90 DAS) }\end{array}$ & $\begin{array}{l}\text { CD } \\
\text { (90 DAS) }\end{array}$ & $\begin{array}{l}\text { HDR } \\
\text { (90 DAS) }\end{array}$ \\
\hline S1 & $8.04 \mathrm{a}$ & $20.84 \mathrm{a}$ & $32.81 \mathrm{a}$ & $4.39 \mathrm{a}$ & $7.48 \mathrm{abc}$ \\
S2 & $8.52 \mathrm{a}$ & $18.91 \mathrm{ab}$ & $32.97 \mathrm{a}$ & $4.40 \mathrm{a}$ & $7.46 \mathrm{abc}$ \\
S3 & $6.75 \mathrm{ab}$ & $13.26 \mathrm{cde}$ & $24.89 \mathrm{bcd}$ & $3.49 \mathrm{bcde}$ & $7.10 \mathrm{bc}$ \\
S4 & $6.38 \mathrm{ab}$ & $10.86 \mathrm{de}$ & $22.21 \mathrm{cde}$ & $3.27 \mathrm{bcde}$ & $6.78 \mathrm{abc}$ \\
S5 & $5.58 \mathrm{~b}$ & $8.86 \mathrm{e}$ & $17.28 \mathrm{e}$ & $2.63 \mathrm{e}$ & $6.60 \mathrm{~cd}$ \\
S6 & $7.38 \mathrm{ab}$ & $18.28 \mathrm{abc}$ & $33.63 \mathrm{a}$ & $3.97 \mathrm{abc}$ & $8.44 \mathrm{a}$ \\
S7 & $7.61 \mathrm{ab}$ & $19.45 \mathrm{a}$ & $31.90 \mathrm{ab}$ & $4.14 \mathrm{ab}$ & $7.68 \mathrm{abc}$ \\
S8 & $8.03 \mathrm{a}$ & $18.34 \mathrm{ab}$ & $29.82 \mathrm{ab}$ & $3.78 \mathrm{abcd}$ & $7.91 \mathrm{ab}$ \\
S9 & $7.55 \mathrm{ab}$ & $18.84 \mathrm{ab}$ & $28.60 \mathrm{abc}$ & $3.98 \mathrm{ab}$ & $7.15 \mathrm{bc}$ \\
S10 & $7.72 \mathrm{ab}$ & $18.58 \mathrm{ab}$ & $31.88 \mathrm{ab}$ & $4.07 \mathrm{ab}$ & $7.80 \mathrm{abc}$ \\
S11 & $6.98 \mathrm{ab}$ & $12.42 \mathrm{de}$ & $21.52 \mathrm{cde}$ & $3.00 \mathrm{de}$ & $7.20 \mathrm{bc}$ \\
S12 & $8.35 \mathrm{a}$ & $18.87 \mathrm{ab}$ & $24.76 \mathrm{bcde}$ & $3.55 \mathrm{abcd}$ & $6.99 \mathrm{bcd}$ \\
S13 & $7.64 \mathrm{ab}$ & $14.14 \mathrm{bcd}$ & $18.00 \mathrm{de}$ & $3.10 \mathrm{cde}$ & $5.84 \mathrm{~d}$ \\
\hline CV $(\%)$ & 13.50 & 14.19 & 12.76 & 10.90 & 7.57
\end{tabular}

Equal letters in the columns do not differ at $5 \%$ probability by the Tukey's test; $\mathrm{CV}=$ coefficient of variation; $\mathrm{BM}=$ bovine manure; $\mathrm{SS}=$ subsurface soil; $\mathrm{BP}=$ Bioplant ${ }^{\oplus} ; \mathrm{FV}=$ superfine vermiculite; $\mathrm{FS}=$ fine sand.

Table 5. Shoot dry mass (SDM), root dry mass (RDM), total dry mass (TDM), shoot/root dry mass ratio (SMR) and root/total dry mass ratio (RMR) of Syzygium cumini seedlings, Cassilândia, MS, Brazil, 2014-2015.

\begin{tabular}{|c|c|c|c|c|c|}
\hline SUBSTRATES & SDM (g) & RDM (g) & TDM (g) & SMR & RMR \\
\hline S1 & $4.93 \mathrm{abc}$ & 3.1 bcde & $8.03 \mathrm{abcd}$ & $1.58 \mathrm{a}$ & $0.38 \mathrm{c}$ \\
\hline S2 & $4.88 \mathrm{abc}$ & $3.47 \mathrm{abcd}$ & $8.36 \mathrm{abc}$ & $1.40 \mathrm{ab}$ & $0.41 \mathrm{abc}$ \\
\hline S3 & 3.76 bcde & 2.68 cde & 6.45 bcde & $1.40 \mathrm{ab}$ & $0.41 \mathrm{abc}$ \\
\hline S4 & $3.35 \mathrm{de}$ & $2.59 \mathrm{de}$ & $5.95 \mathrm{de}$ & $1.29 a b$ & $0.43 a b c$ \\
\hline S5 & 2.89 e & $2.35 \mathrm{e}$ & $5.24 \mathrm{e}$ & $1.23 a b$ & $0.44 \mathrm{abc}$ \\
\hline S6 & $4.87 \mathrm{abc}$ & 3.07 bcde & $7.95 \mathrm{abcd}$ & $1.59 \mathrm{a}$ & $0.38 \mathrm{c}$ \\
\hline S7 & $4.76 \mathrm{abcd}$ & $3.9 a b$ & $8.67 \mathrm{ab}$ & $1.23 \mathrm{ab}$ & $0.44 a b c$ \\
\hline S8 & $5.09 a b$ & $3.43 \mathrm{abcd}$ & $8.53 \mathrm{ab}$ & $1.49 a b$ & $0.40 \mathrm{bc}$ \\
\hline S9 & $5.62 \mathrm{a}$ & $4.13 \mathrm{a}$ & $9.75 \mathrm{a}$ & $1.35 \mathrm{ab}$ & $0.42 a b c$ \\
\hline S10 & $5.19 a b$ & $3.45 \mathrm{abcd}$ & $8.64 a b$ & $1.55 \mathrm{a}$ & $0.40 \mathrm{bc}$ \\
\hline S11 & $3.54 \mathrm{cde}$ & $2.71 \mathrm{cde}$ & $6.26 \mathrm{cde}$ & $1.31 \mathrm{ab}$ & $0.43 a b c$ \\
\hline S12 & $4.39 \mathrm{abcd}$ & $3.64 a b c$ & $8.03 \mathrm{abcd}$ & $1.19 a b$ & $0.45 a b$ \\
\hline $\mathrm{S} 13$ & $2.87 \mathrm{e}$ & $2.62 \mathrm{de}$ & $5.49 \mathrm{e}$ & $1.09 \mathrm{~b}$ & $0.47 \mathrm{a}$ \\
\hline C.V. (\%) & 15.79 & 14.55 & 13.71 & 13.54 & 7.00 \\
\hline
\end{tabular}

Equal letters in the columns do not differ at $5 \%$ probability by the Tukey's test; $\mathrm{CV}=$ coefficient of variation; BM=bovine manure; SS=subsurface soil; BP=Bioplant ; FV= superfine vermiculite; $F S=$ fine sand.

Table 6. Dickson quality index (DQI), relative growth rate (RGR1 and RGR2) and absolute growth rate (AGR1 and AGR2), Cassilândia, MS, Brazil, 2014-2015.

\begin{tabular}{llllll}
\hline SUBSTRATES & DQI & $\begin{array}{l}\text { RGR1 } \\
(30-60 \mathrm{DAS})\end{array}$ & $\begin{array}{l}\text { RGR2 } \\
(60-90 \mathrm{DAS})\end{array}$ & $\begin{array}{l}\text { AGR1 } \\
(30-60 \mathrm{DAS})\end{array}$ & $\begin{array}{l}\text { AGR2 } \\
(60-90 \mathrm{DAS})\end{array}$ \\
\hline S1 & $0.88 \mathrm{abc}$ & $0.032 \mathrm{a}$ & $0.015 \mathrm{cde}$ & $0.42 \mathrm{a}$ & $0.39 \mathrm{abc}$ \\
S2 & $0.94 \mathrm{abc}$ & $0.026 \mathrm{abc}$ & $0.018 \mathrm{abcd}$ & $0.34 \mathrm{ab}$ & $0.46 \mathrm{ab}$ \\
S3 & $0.75 \mathrm{bc}$ & $0.022 \mathrm{abcd}$ & $0.020 \mathrm{abc}$ & $0.21 \mathrm{bc}$ & $0.38 \mathrm{abc}$ \\
S4 & $0.74 \mathrm{bc}$ & $0.018 \mathrm{~cd}$ & $0.024 \mathrm{a}$ & $0.14 \mathrm{c}$ & $0.37 \mathrm{abc}$ \\
S5 & $0.67 \mathrm{c}$ & $0.016 \mathrm{~d}$ & $0.022 \mathrm{ab}$ & $0.10 \mathrm{c}$ & $0.28 \mathrm{cde}$ \\
S6 & $0.79 \mathrm{bc}$ & $0.030 \mathrm{ab}$ & $0.020 \mathrm{abc}$ & $0.36 \mathrm{a}$ & $0.51 \mathrm{a}$ \\
S7 & $0.97 \mathrm{ab}$ & $0.031 \mathrm{a}$ & $0.016 \mathrm{bcd}$ & $0.39 \mathrm{a}$ & $0.41 \mathrm{abc}$ \\
S8 & $0.90 \mathrm{abc}$ & $0.027 \mathrm{abc}$ & $0.016 \mathrm{bcd}$ & $0.34 \mathrm{ab}$ & $0.38 \mathrm{abc}$ \\
S9 & $1.14 \mathrm{a}$ & $0.031 \mathrm{a}$ & $0.014 \mathrm{def}$ & $0.37 \mathrm{a}$ & $0.32 \mathrm{bcd}$ \\
S10 & $0.92 \mathrm{abc}$ & $0.029 \mathrm{ab}$ & $0.018 \mathrm{abcd}$ & $0.36 \mathrm{a}$ & $0.44 \mathrm{abc}$ \\
S11 & $0.73 \mathrm{bc}$ & $0.018 \mathrm{~cd}$ & $0.018 \mathrm{abcd}$ & $0.18 \mathrm{c}$ & $0.30 \mathrm{~cd}$ \\
S12 & $0.98 \mathrm{ab}$ & $0.027 \mathrm{abc}$ & 0.009 ef & $0.35 \mathrm{ab}$ & $0.19 \mathrm{de}$ \\
S13 & $0.79 \mathrm{bc}$ & $0.020 \mathrm{bcd}$ & $0.008 \mathrm{f}$ & $0.21 \mathrm{bc}$ & $0.12 \mathrm{e}$ \\
\hline CV (\%) & 14.63 & 18.34 & 17.58 & 21.32 & 21.12 \\
\hline Equal letters in the columns do not differ at 5\% probability by the Tukey's test; CV $=$ coefficient of variation; BM=bovine manure; SS=subsurface soil; BP=Bioplant; FV= \\
superfine vermiculite; FS=fine sand.
\end{tabular}


use of Bioplant as a substrate material in the production of forest seedlings presented negative results, similar to those achieved in this study.

All the substrates evaluated in the present study showed adequate shoot/root dry mass ratio (SMR), ranging from 1.09 to 1.59 . According to Gomes and Paiva (2004), the mass ratio is one of the main parameters to evaluate the survival and initial growth of seedlings in the field, and seedling survival relates to the root amount and distribution regardless of plant height. In the experiment, the satisfactory distribution between shoot and root dry masses allowed the Syzygium cumini seedlings to adapt to the region of Cassilândia, as well as the physical and chemical characteristics of the tested substrates, which possibly allowed proper aeration and nutrition.

Concerning the RMR, it was verified the worst mass distribution in the plants cultivated in substrates with $50 \%$ bovine manure, in comparison to substrates with $40 \%$ Bioplant . Consequently, in the literature, many authors do not recommend the use of bovine manure above $30 \%$ in substrates (Dias et al., 2009a; Silva et al., 2009; Dias et al., 2009b; Cavalcanti, 2010; Costa et al., 2015). However, other authors have reported high-quality seedlings using more than 30\% bovine manure (Costa et al., 2012).

\section{Morphological indices}

According to Gomes and Paiva (2004), the minimum value to determine the Dickson quality index is 0.20 , and the higher the DQI, the better-quality standard of the seedlings. Thus, all treatments in this study are of the ideal proportions. However, the highest values found for shoot dry mass (SDM), root dry mass (RDM) and total dry mass (TDM) reflect the highest Dickson quality index (DQI), which was 1.14 for substrate S9 (Table 6), whose SDM, RDM, and TDM were 5.62, 4.13 and $9.13 \mathrm{~g}$ per seedling, respectively. These are adequate data for obtaining high-quality seedlings, which are necessary for the survival of these seedlings and successful field planting.

Plant growth analysis is essential because it reports changes in plant production as a function of time. According to Barbieri Júnior et al. (2007), the relative growth rate of a plant, or any organ of the plant, reflect the organic matter increase at a given time, dependent on the living material. In this sense, the seedlings cultivated in substrates S1, S7 and $S 9$ reached $0.03 \mathrm{~cm}$ day $^{-1}$ relative growth rate in height at 30 to 60 DAS, which was higher than that observed in substrates S4, S5, S11, and S13. From 60 to 90 DAS, substrate $\mathrm{S} 4$ showed an increase of $0.02 \mathrm{~cm} \mathrm{day}^{-1}$, which is higher than substrates S1, S7, S8, S9, S12 and S13 (Table 6). From 60 to 90 DAS, it was verified that substrate $S 13$ had lower relative growth rates in comparison to S1, S2, S3, S4, S5, S6, S6, S7, S8, S10, and S11.

Seedlings in substrates S1, S6, S7, S9 and S10 from 30 to 60 DAS showed growth rates between 0.36 and $0.42 \mathrm{~cm}$, which were higher than those in substrates S3, S4, S5, S11, and $\mathrm{S} 13$, whose values ranged between 0.10 and $0.21 \mathrm{~cm} \mathrm{day}^{-1}$. From 60 to 90 DAS, the highest growth was observed in substrate $\mathrm{S} 6(0.51 \mathrm{~cm}$ dia-1), comparing to substrates $\mathrm{S} 5, \mathrm{~S} 9$, S11, S12 and S13 which presented values between 0.12 and $0.30 \mathrm{~cm} \mathrm{day}^{-1}$ (Table 6). It was observed that the Syzygium cumini seedlings in substrates S7 and S9, which contained 10 to $30 \%$ bovine manure and 20 to $40 \%$ vermiculite, were among the highest relative and absolute growth rates in the period from 30 to 60 DAS. Also, these substrates are among those with the highest DQI, total shoot dry mass, plant height and stem base diameter. Finally, it can be said that it is crucial to producing high-quality seedlings before final planting, and with proper management, this practice can be achieved easily and quickly.

\section{Materials and Methods}

\section{the Plant material and site characterization}

Seeds of Syzygium cumini L. (Jambolan) were collected from the orchard trees established in savannah areas located at the Mato Grosso do Sul State University (UEMS), in the municipality of Cassilândia, MS, Brazil (19007'21" S, 51으' 15 " W, and altitude of $516 \mathrm{~m}$ ).

The regional climate according to the Köppen classification is $\mathrm{Aw}$, characterized as the tropical climate with hot summers and a tendency towards high rainfall levels, and dry winters, with a dry season between May and September. The 30-year mean annual temperature is $24.1^{\circ} \mathrm{C}$ with a July minimum of $16.4^{\circ} \mathrm{C}$ and a January maximum of $28.6^{\circ} \mathrm{C}$, and mean annual rainfall of $1,520 \mathrm{~mm}$.

\section{Description of environments}

The experiment was conducted from December 2014 to March 2015 at the State University of Mato Grosso do Sul, University Unit of Cassilândia, MS, Brazil a

The protected environment used for the development of the experiment was a plant nursery of galvanized steel structure $8.0 \mathrm{~m}$ wide $\times 18.0 \mathrm{~m}$ in length and $4.0 \mathrm{~m}$ in height up to the gutter, covered with Aluminet thermo-reflective aluminized $50 \%$-shade cloth. Installed at 3,3 $\mathrm{m}$ from the ground, and black $50 \%$-shade cloth is covering its sidewalls and front. Inside the protected environment were monitored, air temperature $\left({ }^{\circ} \mathrm{C}\right)$, relative humidity $(\%)$, total solar radiation $\left(\mathrm{W} \mathrm{\textrm {m } ^ { - 2 }}\right)$, total and diffuse photosynthetically active radiation $\left(\mu \mathrm{mol} \mathrm{m} \mathrm{s}^{-1}\right)$. Additionally, micrometeorological data were measured by a specific sensor coupled to the GP2 Data Logger from Delta $T$ Devices, installed in the environment geometric center. The system was programmed to perform readings at 10 -second intervals, with averages every minute. Daily it was calculated the average radiation with data monitored from 7:00 a.m. to 6:00 p.m. As for the full sun environment were collected, air temperature, relative humidity and total solar radiation data from the Cassilândia Automatic Weather Station A742-INMET-SONABRA (Figure 1). Irrigation was performed manually with a watering can according to the needs of the seedlings.

\section{Experimental design and trial management}

The seeds were collected from plants in the municipality of Cassilândia, State of Mato Grosso do Sul, Brazil, and they were sowed in 1.8-liter black polyethylene bags $(15.0 \times 25.0$ $\mathrm{cm})$. The bags were filled with several proportions of substrates containing bovine manure (BM), subsurface soil (SS), Bioplant ${ }^{\circ}$ (BP), superfine vermiculite (FV) and fine sand (FS) (Table 1).

The experimental design was completely randomized, comprising 13 treatments with different combinations of 
substrates with five replicates of five seedlings per plot (Table 1).

The bovine manure was purchased from a local slaughterhouse. It was composed of barn manure and rumen material composted for 30 days, then homogenized and dried. The subsurface soil was collected from a $10-30 \mathrm{~cm}$ deep layer at the University Unit of Cassilândia, MS, Brazil, and then it was chemically and physically characterized and sieved (Table 2 and 3 ).

The Bioplant substrate was commercially available and, according to the manufacturer, it contains coconut fiber, pine bark, manure, sawdust, vermiculite, rice hull, ash, agricultural gypsum, calcium carbonate, magnesium, magnesium thermophosphate and additives (fertilizers).

Vermiculite is an industrialized material, obtained by the expansion process of mica (rock), submitted to temperatures of $800^{\circ}$ to $900^{\circ} \mathrm{C}$. It is considered an almost inert material of variable and very light granulometry, composed of silica tetrahedral sheets and iron ( $\mathrm{Fe}$ ) and magnesium (Mg) octahedral sheets, requiring balanced nutrition by constant fertilization. For substrate purposes, it has right aeration conditions, high cation exchange capacity (CEC) and water retention, and is a material free of pathogens and widely used in seedling production.

Two seeds were planted per bag, at a depth of 1 to $3 \mathrm{~cm}$, and after was performed germination, thinning, leaving only one seed per container - the best-developed seed - taking due care to the fact that they are polyembryonic seeds. Sowing took place on December 11, 2014.

\section{Evaluations carried out}

At 30, 60 and 90 days after sowing (DAS), were measured the seedling heights $(\mathrm{H})$ from stem base diameter to shoot tip, using a millimeter ruler, with results expressed in centimeters $(\mathrm{cm})$. At 90 DAS were evaluated, stem base diameter (CD) was measured using a digital caliper, with results expressed in millimeters $(\mathrm{mm})$. Subsequently, shoot dry mass (SDM), root dry mass (RDM) and total dry mass (TDM). The biological material was oven dried in a forced air circulation at a temperature of 65 o C until reaching a constant mass to obtain the masses, which was measured using an analytical balance with data expressed in grams. Also, it was evaluated the height/stem base diameter ratio (HDR), shoot/root dry mass ratio (SMR), root/total dry mass ratio (RMR) and Dickson quality index (DQI). It was calculated the absolute growth rate (AGR) and the relative growth rate (RGR).

\section{Statistical nalysis}

The data were submitted to analysis of variance by the F-test and, when significant, the averages were compared at 5\% probability by the Tukey's test.

\section{Conclusion}

Substrates S7 and S9 containing 10 to $30 \%$ bovine manure and vermiculite 20 to $40 \%$ yielded the best Syzygium cumini seedlings, with adequate stem base diameter, mass ratios, and Dickson quality indexes.
Substrates S1, S6, and S10, with the largest amounts of bovine manure $(50 \%)$, showed the worst distributions of dry masses (SMR and RMR).

Substrates with high amounts of Bioplant ${ }^{\natural}(\mathrm{S} 11, \mathrm{~S} 12, \mathrm{~S} 13)$ or fine sand $(\mathrm{S} 3, \mathrm{~S} 4, \mathrm{~S} 5)$ are not recommended for the formation of Syzygium cumini seedlings.

\section{Acknowledgments}

To the Foundation for the Support and Development of Education, Science and Technology of the State of Mato Grosso do Sul (FUNDECT/UEMS) and the Coordination for the Improvement of Higher Education Personnel (CAPES) for financial support and granting of scholarships. To the Support Program for Emerging Centers (PRONEM-MS), Call Notice FUNDECT/CNPq No. 15/2014, Granting Term No. 080/2015 SIAFEM: 024367. To the FUNDECT/PPP (First Projects Program), Call Notice No. 05/2011, Proc. No. 23/200.647/2012, Granting Term No. 0152/12 SIAFEM: 020865.

\section{References}

Alves EU, Moura SSS, Moura MF, Guedes RS, Estrela FA (2012) Germinação e vigor de sementes de Crateava tapia L. em diferentes substratos e temperaturas. Rev Bras Frutic. 34(4): 1208-1215.

Arrua LLC, Costa E, Bardiviesso EM, Nascimento DM, Binotti FFS (2016) Protected environments and substrates for mangabeira seedlings (Hancornia Speciosa Gomez) production. Eng Agrí. 36(6):984-995.

Barbieri Júnior D, Braga FL, Roque CG, Sousa MP (2007) Análise de crescimento de hymenaea courbaril L. sob efeito da inoculação micorrizica e adubação fosfatada. Rev Ciênc Agro Ambient. 5(1):1-15.

Borges KCF, Santana DG, Lopes SW, Pereira VJ (2016) Coloração do Fruto e Substrato na Emergência e no Crescimento de Plantas de Eugenia calycina Cambess. Floresta Ambient. 23(4):544-554.

Carneiro JGA (1995) Produção e Controle de Qualidade de Mudas Florestais. FUPEF, Curitiba, BR.

Cavalcanti NB (2010) Influência de diferentes substratos na emergência e crescimento de plântulas de Jambolão (Syzygium jambolanum Lam.). Eng Ambient. 7(2):241-251.

Cavalcanti NB (2011) Crescimento inicial de plantas de Jambolão (Syzygium jambolanum Lam.) em diferentes substratos. Eng Ambient. 8(4):164-182.

Costa E, Oliveira LC, Espírito Santo TL, Leal PAM (2012) Production of baruzeiro seedling in different protected environments and substrates. Eng Agrí. 32(4):633-641.

Costa E, Dias JG, Lopes KG, Binotti FFS, Cardoso ED (2015) Telas de Sombreamento e Substratos na Produção de Mudas de Dipteryx alata Vog.. Floresta Ambient. 22(3):416-425.

Dias TJ, Pereira WE, Cavacante LF, Raposo RWC, Freire JLO (2009a) Desenvolvimento e qualidade nutricional de mudas de mangabeiras cultivadas em substratos contendo fibra de coco e adubação fosfatada. Rev Bras Frutic. 31(2):512-523.

Dias R, Melo B, Rufino MA, Silveira DL, Morais TP (2009b) Fontes e proporção de material orgânico para a produção de mudas de cafeeiro em tubetes. Ciênc Agrotec. 33(3):758-764. 
Dutra TR, Grazziotti PH, Santana RC, Massad MD (2012) Desenvolvimento inicial de mudas de copaíba sob diferentes níveis de sombreamento e substratos. Rev Ciênc Agron. 43(2):321-329.

Gomes JM, Paiva HN (2004) Viveiros florestais: propagação sexual. UFV, Viçosa, BR.

Gomes JM, Paiva HN (2012) Viveiros florestais: propagação sexuada. UFV, Viçosa, BR.

Lima IMO, Silva Júnior JS, Costa E, Cardoso ED, Binotti FFS, Jorge MHA (2016) Diferentes substratos e ambientes protegidos para o crescimento de mudas de maracujazeiro amarelo doce. Rev Agric Neot 3(4):39-47.

Mazzanti CM, Schossler DR, Filappi A, Prestes D, Balz D, Miron V, Morsch A, Schetinger MRC, Morsch VM, Cecim M (2003) Extrato da casca de Syzygium cumini no controle da glicemia e estresse oxidativo de ratos normais e diabéticos. Ciênc Rural, 33(6):1061-1065.
Oliveira FG, Jardim MAG (2013) Substratos na produção de mudas de espécies arbóreas nativas para arborização urbana. REVSBAU, 8(3):29-38.

Sanches CF, Costa E, Costa GGS, Binotti FFS, Cardoso ED (2017) Hymenaea courbaril seedlings in protected environments and substrates. Enge Agríc. 37(1):24-34.

Smiderle OJ, Salibe AB, Hayashi AH, Minami K (2001) Produção de mudas de alface, pepino e pimentão em substratos combinando areia, solo e Plantmax. Hort Bras. 19(3):253-257.

Silva EP, Maruyama WI, Oliveira AC, Bardiviesso DM (2009) Efeito de diferentes substratos na produção de mudas de mangabeira (Hancornia speciosa G). Rev Bras Frutic. 31(3):925-929.

Souza VC, Lorenzi H (2005) Botânica Sistemática: guia ilustrado para identificação das famílias das Angiospermas da flora brasileira, baseado em APGII. Instituto Plantarum, Nova Odessa, São Paulo, BR. 